\title{
Challenges to Formality From fORMAL FIRMS BEHAVING INFORMALLY: EVIDENCE FROM Central America
}

Michael J. Pisani*

DOI: 10.5377/EYA.V12I2.12974

Recived: 25/05/2021 Accepted: 30/11/2021

\begin{abstract}
This research explores the competitive environment for urban formal sector firms competing against peer formal sector firms behaving informally in Central America. Explored is the upper bound of the formalinformal continuum in a regional economic environment of persistent and widespread economic informality where formal firms may employ informal tactics to gain competitive advantage versus their formal competitors. The 2010 World Bank Enterprise Surveys form the basis for empirical analyses. The results suggest formal firms utilizing informal practices is widespread and is influenced by firm maturity, firm location, industry sector, firm legal status, firm organization, ownership composition, regulatory environment, international quality certification, web presence, entry into global markets, and firm size.
\end{abstract}

KEYWORDS: Competition, Formal Sector, Informal Tactics, Central America

JEL: L10, 017, 054

\footnotetext{
* Professor of International Business, Department of Management, College of Business Administration, Central Michigan University, ORCID 0000-0001-7773-5951 Email: m.pisani@cmich.edu, , Google Scholar: https://scholar.google.com/citations?user=Py0JjYsAAAAJ\&hl=en, Mt. Pleasant, Michigan USA.
} 


\title{
Desafíos PARA LA FORMALIDAD DE LAS EMPRESAS FORMALES QUE SE COMPORTAN DE MANERA informal: EvidenCiA DE CENTROAMÉRICA
}

\author{
Michael J. Pisani*
}

DOI: 10.5377/EYA.V1212.12974

Recibido: 25/05/2021 Aceptado: 30/11/2021

\section{RESUMEN}

Esta investigación explora el entorno competitivo de las empresas del sector formal urbano que compiten con empresas del sector formal pares que se comportan de manera informal en Centroamérica. Se explora el límite superior del continuo formal-informal en un entorno económico regional de la informalidad económica persistente y generalizada donde las empresas formales pueden emplear tácticas informales para obtener una ventaja competitiva frente a sus competidores formales. Las encuestas de empresas del Banco Mundial de 2010 constituyen la base de análisis empíricos. Los resultados sugieren que las empresas formales que utilizan prácticas informales están muy extendidas y están influenciadas por la madurez de la empresa, la ubicación de la empresa, el sector industrial, el estado legal de la empresa, la organización de la empresa, la composición de la propiedad, el entorno regulatorio, la certificación de calidad internacional, la presencia en la web, la entrada a los mercados globales, y el tamaño del negocio.

PALABRAS CLAVES: competencia, sector formal, tácticas informales, Centroamérica.

JEL: L10, 017, 054.

\footnotetext{
*Profesor de negocios internacionales, departamento de gestión, facultad de administración de empresas, Central Michigan University, ORCID 0000-0001-7773-5951 Correo electrónico: m.pisani@cmich.edu Google Scholar: https://scholar.google.com/ citations? user=Py0JjYsAAAAJ\&hl=en, Mt. Pleasant, Michigan EE.UU.
} 


\section{INTRODUCTION}

In the developing world, economic informality is a way of life for most. From consumers and producers, few are immune to the reach of the informal economy in emerging markets (Neuwirth, 2011). This reach into the informal economy may be by choice and/or compulsion, yet participate they do. And for the very few in the developing world that do not participate at all in the informal economy, they are surely knowledgeable of its existence.

Within this environment, businesses emerge, some fully exempt from informality, but most engaged to some degree with informality (De Soto, 2000). The larger macro-environment has been explained elsewhere and may be due in part to economic structures (Bienefeld, 1975), bureaucratic malaise (De Soto, 2000), and labor surpluses (House, 1984). More directly for this present study, informality exists on a continuum of participation, not only for economies (Williams \& Youseff, 2014), but also for businesses (Pisani, 2019a; Richardson \& Pisani, 2012, Williams, 2020). This article explores an understudied portion of this continuum: formal firms competing against other formal firms employing informal tactics within the geographic space of Central America.

Much of the literature on informality in developing or emerging markets focuses upon the production of informal goods and services. Fewer studies still, spotlight the consumption of informal products (Pisani \& Pisani, 2018, Pisani, 2013). Almost absent from the literature are works that consider the incorporation of informal practices into formal competitive tactics (see Pisani, 2019b, 2015, Vallanti and Gianfreda, 2021, for exceptions). As this research stream is exploratory, the following research question is the focus of the paper: "What impact, if any, does competition from formal enterprises behaving, in part, informally have on formal firms within a largely informal regional economic environment?"

The remainder of this paper is organized as follows, section two reviews the relevant literature and Central American socio-economic context, section three describes the methodology, section four presents the results and discussion, and the last section concludes the paper. 


\section{LITERATURE REVIEW}

There are few studies that focus on informal firm behavior in Central America. Pisani and Patrick (2002)argue that facilitating informality in the region may lead to greater economic growth and perhaps better prospects for informal firms to outgrow the informal sector and contribute even more to a robust formal sector. Pisani (2019b) explores the more conventional route of once informal enterprises becoming formal businesses in urban El Salvador. Primary determinants toward formality in this case include a very central location in the capital, competitive obstacles imposed by informal competitors, and gang violence revealing safer business terrain in the formal sector. However, there are occasions in Central America when the informal sector maximizes one's economic returns depending upon the larger socio-political environment (Pisani \& Pagán, 2004).

Pisani (2017, 2016) and Pisani and Yoskowitz (2012) describe the impact and opportunities of informality upon small in-home convenience stores or tienditas in Central America. This line of investigation is limited to one, albeit vary large, business segment of a primarily informal endeavor. In general, this market segment is an economic refuge and supplement for household economic survival and a repository of female entrepreneurship. Nevertheless, a small percentage of tienditas are able to grow and prosper, utilizing specific business tools and attributes such as bookkeeping and retail location in enhancing business success. More broadly focused on labor informality rather than enterprise informality, Funkhouser (1996) describes the Central American informal sector in the 1980s and early 1990s, particularly the determinates of employment and economic returns to informal sector participation. Pisani (2003) undertakes a similar analysis for Nicaragua during the 1990s.

The literature is sparse concerning the complexity of intra-firm rivalry utilizing multiple informal tactics. Richardson and Pisani (2012) study the many ways in which informal enterprises along the US-Mexico border in South Texas seize opportunities to survive - such as arbitraging cost, social networks, or cross-border transit channels. More directly, Pisani (2015) explores the nuances of informal tactics utilized by formal firms within Nicaragua. He finds that such informal competitive pressures exist and are exploited within the formal sector. There are several practices that are part and parcel with informality: cash transactions, undocumented sales (e.g., no receipt or sales record), irregularities with sales taxes/value added taxes ${ }^{1}$ (e.g., non-collection of tax or collection and non-transmittal of tax receipts to government), and the use of irregular labor ${ }^{2}$ to avoid recorded business activity and concomitant government compliance and transfers (Pisani, 2013, Portes, et al., 1989). As these informal practices seek by design to avoid government detection, it is difficult to ascertain such complete information. However, two of these practices are surveyed for formal firms within the World Bank's Enterprise Survey; these are the omission of sales receipts/records and the use of unprotected labor by competing firms.

As developing economies exhibit an informal-formal continuum, many formal sector firms also employ informal methods when competing against rival formal firms. It is this consideration-firm-level competition from the perspective of the formal firm from peer formal firms acting informally - that is the focus of this research within the Central American environment.

\footnotetext{
${ }^{1}$ This may also include tax avoidance, underreported income, and dual bookkeeping records (one for business operations, one for government inspection).

${ }^{2}$ Irregular labor practices may result in the disenfranchisement in social security and labor rights neglect (e.g., safe work environment, overtime pay, and the right to organize).
} 


\subsection{The Central American socio-economic environment}

For the purposes of this study, Central America includes all seven countries- Belize, Costa Rica, E1 Salvador, Guatemala, Honduras, Nicaragua, and Panama - of the Central American isthmus. Some scholars exclude Belize and Panama from the study of Central America because of the historical unity among Guatemala, El Salvador, Honduras, Nicaragua and Costa Rica during the Spanish colonial period and the immediate post-colonial confederation (Booth, Wade, \& Walker, 2015), but this view is limiting. ${ }^{3}$ This investigation takes an inclusive approach that includes the whole Central American region as reflected in the contemporary Sistema de la Integración Centroamericana (SICA), a regional organization that promotes economic and political development and integration that includes all seven nations as members. ${ }^{4}$

The Central American nations in this study are not large or populous by hemispheric standards, though more reside in urban areas than those in rural regions. The information provided in Table 1 reflects the timeframe (2010) in which the data collected for this study was undertaken. Even so, Belize is relatively underpopulated with only 15 people per square kilometer. On the other end of the population spectrum, both E1 Salvador and Guatemala have the highest population densities and Guatemala the largest population. As with population, the economies of the region are relatively small ranging in size from $\$ 1.4$ billion (Belize) to $\$ 41.4$ billion (Guatemala). ${ }^{5}$ While the region is in many ways similar and may be grouped together, it is by no means a homogenous region (West \& Augelli, 1976).

Nicaragua is the second poorest country in the hemisphere (Haiti is the poorest) with a 2010 per capita GDP of $\$ 1,470$; Honduras also has a per capita income of under $\$ 2,000$. Panama and Costa Rica boast middling per capita income levels with the remainder in between. Nearly half to three-quarters of the economically active non-agricultural population in the region works under condition of informality (Funkhouser, 1996). The Central American economies exhibit a large degree of openness to the global market where imports and exports comprise a substantial portion of overall economic activity. Connectivity to the Internet is not widespread and quite low in the poorest countries in the region. On the other hand, the Human Development Index (HDI), a combination of life expectancy, education, and income, indicates an average to above average ranking within the developing world for Central America. Yet income is highly unequally distributed (as reflected in the GINI index), so the averages discussed above disguise the disparity between the haves and have-nots. ${ }^{6}$

\footnotetext{
${ }^{3}$ Though Belize gained independence from Great Britain in 1981 and is officially a part of the British Commonwealth, it is situated in the Maya cultural hearth and has a plurality of Spanish speakers and a fast-growing Central American-origin population. Since independence, Belize has become increasingly integrated with its isthmian neighbors, economically, politically, and serves as a cultural bridge between Central America and the Commonwealth Caribbean (Pisani \& Pisani, 2007). Panama, historically a component of, yet distinctive from Colombia, achieved independence in 1903, and has served as a maritime conduit between the Pacific and the Atlantic (via the Caribbean Sea) since the opening of the Panama Canal in 1914.

${ }^{4}$ The Dominican Republic became a full member of SICA in 2013 reflecting the region's economic membership in the Central American Free Trade Agreement plus the Dominican Republic with the United States.

${ }^{5}$ All monetary figures are in US dollars.

${ }^{6} \mathrm{Also}$ not indicated is the violence that has driven many young people from Guatemala, E1 Salvador, and Honduras (the northern triangle) and more recently the political violence in Nicaragua to seek a new life in the United States.
} 
Table 1 Basic Indicators for Central America (2010)

\begin{tabular}{|c|c|c|c|c|c|c|c|}
\hline Indicator & Belize & Costa Rica & El Salvador & Guatemala & Honduras & Nicaragua & Panama \\
\hline Area $(\mathrm{sq} \cdot \mathrm{km})^{\wedge}$ & 22,810 & 51,060 & 20,720 & 107,160 & 111,890 & 120,340 & 74,340 \\
\hline Population ^^ & 309 & 4,669 & 6,218 & 14,341 & 7,621 & 5,822 & 3,678 \\
\hline \multicolumn{8}{|l|}{ (in 1000s) } \\
\hline Population Density & 15 & 95 & 306 & 144 & 72 & 51 & 52 \\
\hline \multicolumn{8}{|l|}{ (People per sq. km) } \\
\hline 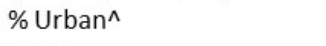 & 45 & 72 & 64 & 49 & 52 & 57 & 65 \\
\hline GDP^ & 1,399 & 36,298 & 21,418 & 41,338 & 15,839 & 8,938 & 28,814 \\
\hline \multicolumn{8}{|l|}{ (in \$US millions) } \\
\hline Per Capita GDP^ & 4,380 & 6,910 & 3,350 & 2,750 & 1,890 & 1,470 & 8,050 \\
\hline \multicolumn{8}{|l|}{ (in \$US) } \\
\hline \% Employment in Informal & 46.8 & 43.8 & 66.4 & 72.3 & 75.3 & 65.7 & 43.8 \\
\hline \multicolumn{8}{|l|}{ Sector+ } \\
\hline Economic Openness^^ & 0.74 & 0.79 & 0.69 & 0.62 & 1.09 & 0.85 & 1.40 \\
\hline Internet Users^\# & 31.7 & 46.0 & 23.1 & 19.7 & 17.8 & 15.5 & 42.9 \\
\hline \multicolumn{8}{|l|}{ (per 100 people) } \\
\hline $\mathrm{HDI} \sim$ & .714 & .750 & .652 & .613 & .612 & .604 & .759 \\
\hline GINI Index & .531 & .507 & .483 & .559 & .570 & .405 & .519 \\
\hline
\end{tabular}

\section{Methodology}

The 2010 Enterprise Surveys for Central America comprise the seven country level data sets used in this study and 2010 are the latest available surveys for the region collectively. The enterprise surveys were undertaken by the International Finance Corporation of the World Bank (WB) and are archived at the WB. ${ }^{7}$ The WB enterprise survey series "is a firm-level survey of a representative sample of an economy's private sector" (World Bank Group, 2013). Since 2006, this survey has been deployed in 148 countries covering more than 171,000 firms.

The standard questionnaire contains about 200 questions recorded in 13 main sections: firm-level demographics, general information, infrastructure and services, sales and supplies, innovation and degree of competition, land and permits, crime, finance, business development services, business-government relations, labor, business environment, and performance. The WB's Enterprise Survey sampling objectives (methodology) used for its Central American samples include: randomization; representativeness of the private sector excluding agriculture; sufficient number of respondents for robust statistical testing; stratification by firm size of permanent workers (i.e., small, 5-19 employees; medium, 20-99 employees; and large, 100 or more employees), industry (except agriculture, financial intermediation, real estate and renting activities, the public sector, and utilities), and location (e.g., the capital, major urban areas, and the rest of the country) (World Bank, 2013). ${ }^{8}$ Due to missing

\footnotetext{
7 The data is housed at http://microdata.worldbank.org/index.php/catalog/enterprise_surveys and was released for non-WB purposed research in 2012 and 2013.
} 
data, firm sales could not be used as a control variable; however this limitation may be partially overcome using the number of employees as a proxy of firm size. In essence, the WB Enterprise Surveys reflects a random sample of firms in the urban formal sector.

The Central American enterprise surveys utilized in this research were administered between July 2010 and October 2011, with most of the survey work completed by May 2011. ${ }^{9}$ Non-respondents ${ }^{10}$ were replaced with like firms to achieve the desired sampling frame.

Because of the small size of Belize, location was recorded as Belize and not broken down by specific urban center (e.g., capital city and the rest of the country). Also, the Belize survey took place entirely in 2011 (from August through October) and did not distinguish retail firms. In all, the following number of surveys were completed by country: Belize ( $\mathrm{n}=150)$, Costa Rica ( $\mathrm{n}=538)$, E1 Salvador ( $\mathrm{n}=360)$, Guatemala ( $\mathrm{n}=590)$, Honduras $(n=360)$, Nicaragua $(n=336)$, and Panama $(n=365)$. The WB provides weight estimates for analyzing the data in order to generalize to the population as a whole. The median weight assumption, where firm identification was verified, was chosen as the appropriate measure for this investigation. Overall, the WB describes the data for Central America as is in good condition.

The present research seeks to answer the following research question: "What impact, if any, does competition from formal enterprises behaving, in part, informally have on formal firms within a largely informal regional economic environment?" The enterprise survey asks specifically: "Does this establishment compete against registered firms selling goods or services without records or receipt?" and "Does this establishment compete against registered firms hiring workers without formal contracts?" This is a very important competitive aspect of Central American economies as between 20\% to 60\% of formal firms in the region face competition from peer formal firms using, to some degree, informal practices. Additionally, these two questions allow for a dichotomous dependent variable (yes [ coded as equal to 1 or $=1] /$ no [coded as equal to zero or $=0$ ]) and the use of logistic regression to estimate the likelihood of competition and its impact via formal firms behaving, in part, informally using a set of independent variables drawn a priori from the various question sections detailed above. Logistic regression is a robust statistical tool with few assumption requirements and is an appropriate statistical tool to address the research question (Pampel, 2000).

The following set of a priori independent variables available in the Enterprise Surveys were utilized: firm age (in years), firm location (capital=1), industry classification (manufacturing [the reference category], retail, other services), legal status of the firm (sole proprietorship/family business [the reference category], public corporation, private corporation, partnership, other NGO/don't know), focal firm part of a larger firm (yes=1), female ownership participation (yes=1), percent of time senior management spends dealing with government regulations, international recognized quality certificate (yes=1), website presence (yes=1), export (yes=1), and number of full-time employees.

\footnotetext{
${ }^{8}$ The enterprise survey country-level datasets limit the analysis by: 1) including only urban formal sector firm-level respondents; 2) precluding in most instances regional distinctions either by district or urban center; and 3) aggregating many disparate service-oriented firms under the industry group "other services" for three sectors in toto: manufacturing, retail, and other services (World Bank, 2009).

${ }^{9}$ The survey implementation information is derived from the country 2010 Implementation Reports available at: http://microdata.worldbank. org/index.php/catalog/enterprise_surveys.

${ }^{10}$ Non-response rates for each country were as follows: Belize, 38\%; Costa Rica, 45\%; E1 Salvador, 23\%; Guatemala, 36\%; Honduras, 18\%; Nicaragua, 19\%; and Panama, 49\%.
} 
It is anticipated that six variables-location, legal status of the firm, firm composition (e.g., the firm is part of a larger firm), female ownership participation, quality certification, and exports-will reduce the odds of formal peer firms participating in informal tactics. As the capital city is the heart of government and government authority and enforcement, firms located in the capital are expected to face fewer competitors utilizing informal practices. Most firms in the Central America are small businesses, either classified as sole proprietorships, family businesses, or private corporations depending upon the country. Because of the nature of the statistical method employed (logistic regression), a single reference category must be chosen. In this paper, sole proprietorships/family businesses form the foundational legal status of the firm, hence partnerships and other legal forms should face lower odds of peer formal firms competing informally because their numbers are fewer and easier to detect. Public corporations, because of their enhanced resource endowments, should be more able to deflect, detect, and report peer competitors operating informally. Private corporations, depending upon the reporting milieu in the survey area, may pose mixed results. Surveyed formal firms that are part of larger firms should possess more complex organizational structures and this complexity ought to spill over into their product offerings making it more difficult for competitors to imitate or engage in informal tactics.

In most countries under study, female ownership participation is underrepresented. This underrepresentation may suggest more determined ownership reduces the likelihood of peer competitors. Firms possessing an internationally recognized quality certification enjoy a core competency difficult to reproduce; hence these firms should find themselves less hindered by peers utilizing informal tactics. Exporters too are relatively few and should be effectively shielded from peers operating, in part, informally because of their uniqueness and reputation especially within emerging economies.

It is anticipated that for four variables-firm age, senior management time spent dealing with government regulation, website presence, and firm size (by number of employees) - the impact of utilizing informal tactics by formal firms may be mixed or indeterminate. Older firms may be more visible targets to compete against using informal means (to gain competitive advantage). Yet more mature firms may possess more resources to effectively fight back against peer competitors utilizing informal tactics. When senior management spends more time dealing with government regulations, this suggests a more complex legal-political environment. This complexity may make it more difficult for competitors to enter the same competitive landscape; alternatively, it may open opportunities for competitors to skirt the law (reduce costs and perhaps price) in environments with weak enforcement regimes. Website presence suggests some technological acuity or resources to outsource such knowhow. However, it is relatively easy to enter cyberspace, so the impact of a website presence is anticipated as indeterminate. Lastly, firm size as measured by number of employees may dampen the effect of competitors utilizing informal tactics because of the ability to achieve local economies of scale and scope. On the other hand, smaller albeit formal competitors may be nimbler and relatively hidden from government oversight and may utilize informal tactics to better compete against their larger rivals. 


\section{RESULTS}

In this section, the descriptive statistics of the samples are presented collectively; for precision, the results of the multivariate analyses are reported by individual country. This section concludes with a summary and discussion of the results.

\section{I Descriptive statistics}

The urban (non-agricultural) formal sector comprises the representative sample of Enterprise Survey firms in Central America. A clear majority of sampled firms are in the capital of each country, reflective of the capital's role as the urban and economic hub of the nation (see Table 2). The sampled industry sectors include manufacturing, retail, and other services which are generally proportionally represented with manufacturing typically the least represented. While manufacturing and retail are standard classifications, other services or other service providers include many disparate services from hotels to transportation service, import and export services, wholesale activities, and computer and television repair. A majority of firms are sole proprietorships and family businesses or private corporations. For Costa Rica, E1 Salvador and Panama, the classification of private corporations appears to replace sole proprietorships/family businesses. Partnerships and NGOs comprise the remainder of the firms, and their numbers are only notable in Belize.

Most firms surveyed are stand-alone business enterprises, though just over one-third of surveyed firms in El Salvador are part of larger business organizations. Women are important within the ownership structure of surveyed firms with a majority of enterprises in Nicaragua exhibiting some female ownership. ${ }^{11} \mathrm{~A}$ select few firms, ranging $0.7 \%$ in Belize to $23.6 \%$ in Panama, possess or are in the application process for an internationally recognized quality certification. About half of the firms in Costa Rica, El Salvador, and Guatemala have an internet presence through an online business website; the remaining firms in other Central American countries much less so. Fewer than one-third of respondent firms export, with the most exporters proportionally located in El Salvador and Belize. The average age of firms in the survey ranges from 16.3 years in Panama to 24.8 years in Nicaragua. The average number of employees in the firms surveyed ranges from 21.4 in Nicaragua to 93.0 in Guatemala. This average is higher than the national average due to survey design where firms between 5-19 employees, 20-99 employees, and over 100 employees were purposefully surveyed.

\footnotetext{
${ }^{11}$ See Pisani (2018) for further exploration of female entrepreneurship in Nicaragua.
} 
Table 2 Descriptive Statistics - 2010 Central American Enterprise Survey.

\begin{tabular}{|c|c|c|c|c|c|c|c|}
\hline Variable* & Belize & Costa Rica & El Salvador & Guatemala & Honduras & Nicaragua & Panama \\
\hline \multicolumn{8}{|l|}{ Firm Location (\%) } \\
\hline Capital City & - & 77.0 & 61.5 & 64.8 & 59.7 & 60.8 & 66.6 \\
\hline Rest of the Country & - & 23.0 & 38.5 & 35.2 & 40.3 & 39.2 & 33.4 \\
\hline \multicolumn{8}{|l|}{ Industry Classification (\%) } \\
\hline Manufacturing & 21.0 & 17.8 & 23.4 & 23.2 & 27.0 & 39.1 & 14.9 \\
\hline Retail & - & 22.5 & 29.1 & 24.2 & 33.7 & 32.7 & 36.2 \\
\hline Other Services & 79.0 & 59.7 & 47.5 & 52.6 & 39.3 & 28.2 & 48.9 \\
\hline \multicolumn{8}{|l|}{ Legal Status of the Firm (\%) } \\
\hline Public Corporation & - & 26 & 5.0 & 6.5 & 9.5 & 19.0 & 36.3 \\
\hline Private Corporation & 19.6 & 86.8 & 75.7 & 50.9 & 41.4 & 18.0 & 56.7 \\
\hline Sole Proprietorship/Family Business & 60.5 & 1.6 & 17.7 & 39.2 & 38.0 & 54.6 & 5.8 \\
\hline Partnership & 20.0 & 1.2 & 1.4 & 2.4 & 6.5 & 8.1 & 1.1 \\
\hline NGO/Other/Don't Know & - & 7.9 & 0.2 & 1.0 & 4.5 & 0.3 & 0.0 \\
\hline \multicolumn{8}{|l|}{ Focal Firm Part of a Larger Business? (\%) } \\
\hline Yes & 5.3 & 13.5 & 33.9 & 17.9 & 23.8 & 12.8 & 8.4 \\
\hline No & 94.7 & 86.5 & 66.1 & 82.1 & 76.2 & 87.2 & 91.6 \\
\hline \multicolumn{8}{|l|}{ Any of the Firm Owners Female? (\%) } \\
\hline Yes & 30.4 & 43.5 & 40.2 & 44.2 & 43.3 & 61.5 & 24.7 \\
\hline No & 69.6 & 56.5 & 59.8 & 55.8 & 56.7 & 38.5 & 75.3 \\
\hline \multicolumn{8}{|c|}{ Focal Firm Possess or is in the Application Process for an Internationally Recognized Quality Certificate (\%) } \\
\hline Yes (or in process) & 0.7 & 15.6 & 18.0 & 15.0 & 16.8 & 17.8 & 23.6 \\
\hline No & 99.3 & 84.4 & 82.0 & 85.0 & 83.2 & 82.2 & 76.4 \\
\hline \multicolumn{8}{|l|}{ Focal Firm has a Website (\%) } \\
\hline Yes & 27.7 & 54.0 & 51.9 & 49.9 & 35.3 & 36.9 & 40.5 \\
\hline No & 72.3 & 46.0 & 48.1 & 50.1 & 64.7 & 63.1 & 59.5 \\
\hline \multicolumn{8}{|l|}{ Does Firm Export? (\%) } \\
\hline Yes & 21.2 & 11.3 & 31.3 & 17.7 & 1.4 & 12.5 & 10.2 \\
\hline No & 78.8 & 88.7 & 68.7 & 82.3 & 98.6 & 87.5 & 89.8 \\
\hline Mean Firm Age - Years & 17.2 & 20.3 & 19.1 & 23.7 & 22.7 & $24.8(16.1)$ & 16.3 \\
\hline (std. dev.) & (12.8) & (15.5) & (15.3) & (17.6) & (12.4) & & $(12.8)$ \\
\hline \multirow[t]{2}{*}{ Mean Number of Fulltime Employees (std. dev.) } & 21.5 & 64.0 & 50.6 & 93.0 & 52.3 & $21.4(263.9)$ & 33.1 \\
\hline & (46.6) & (203.0) & (128.7) & (403.9) & (170.2) & & $(63.6)$ \\
\hline N (weighted) & 759 & 7,884 & 5,128 & 9,970 & 5,568 & 1,960 & 5,947 \\
\hline
\end{tabular}

Source: Author's calculations from the 2010 country level Enterprise Surveys.

*Some totals may not add up to $100 \%$ due to rounding errors.

The Enterprise Surveys permit an exploration of two informal tactics used by formal sector firms in competition against other domestic formal sector firms. First, over half of formal firms in El Salvador, Guatemala, Honduras, Nicaragua, and Panama report competing against like or peer formal firms that sell goods or services without records or receipts (see Table 3). It is only in Belize and Costa Rica that report this tactic is utilized by a minority of formal sector enterprises, yet use of the tactic is widespread across Central America. Second, it is majority practice of formal sector competition to hire some workers without formal contracts within formal firms in Costa Rica, El Salvador, Honduras, and Nicaragua. It is also a pervasive practice in the remaining Central American countries. For formal enterprises in El Salvador, Honduras, and Nicaragua, these two tactics are employed by a majority of competitors in the formal economy (this is nearly so for Guatemala). Hence, it is clearly the case that substantial competition exists from formal firms employing informal tactics, often in concert, in the region. ${ }^{12}$

\footnotetext{
${ }^{12}$ Correlations between the two questions are reported in Table 3 (Pearson's R) and range from a high of .892 in Honduras to a low of .316 in Costa Rica. Generally, the responses to these two questions are correlated. As described below, the determinants of utilizing informal tactics varies.
} 
Table 3 Formal Firms Competing Against Peer Formal Firms Using Informal Tactics

\begin{tabular}{|c|c|c|c|c|c|c|c|}
\hline Enterprise Survey Questions* & Belize & Costa Rica & El Salvador & Guatemala & Honduras & Nicaragua & Panama \\
\hline \multicolumn{8}{|c|}{ Does this firm compete against registered firms selling goods/service without records or receipts? (\%) } \\
\hline Yes & 39.2 & 19.8 & 54.0 & 50.1 & 56.0 & 55.4 & 51.1 \\
\hline No & 55.2 & 75.1 & 43.9 & 40.7 & 33.6 & 37.1 & 48.7 \\
\hline Don't Know & 5.6 & 5.1 & 2.1 & 9.2 & 10.4 & 7.5 & 0.2 \\
\hline \multicolumn{8}{|c|}{ Does this firm compete against registered firms hiring workers without formal contracts? (\%) } \\
\hline Yes & 27.0 & 59.5 & 61.4 & 47.2 & 53.6 & 54.8 & 35.3 \\
\hline No & 51.2 & 31.9 & 27.9 & 33.6 & 33.6 & 31.9 & 57.7 \\
\hline Don't Know & 21.8 & 8.6 & 10.7 & 19.1 & 12.8 & 13.4 & 7.1 \\
\hline \multicolumn{8}{|c|}{$\begin{array}{l}\text { Correlation Between firms competing against registered firms selling goods/service without records or receipts and firms competing against registered firms } \\
\text { hiring workers without formal contracts (don't know answers omitted) }\end{array}$} \\
\hline Pearson's R & $.683 \neq$ & $.316 \neq$ & $.618 \ddagger$ & $.750 \neq$ & $.892 \ddagger$ & $.638 \ddagger$ & $.602 \ddagger$ \\
\hline $\mathrm{N}$ (weighted) & 759 & 7,884 & 5,128 & 9,970 & 5,568 & 1,960 & 5,947 \\
\hline
\end{tabular}

*Totals may not add up to $100 \%$ due to rounding errors.

Bold: Represents significance at the $¥ \mathrm{P}<0.01$ level.

Source: Author's calculations from the 2010 Enterprise Surveys.

\subsection{Multivariate analysis - formal firms competing against formal firms using informal tactics}

This section reports the results of logistic regression analyses that examine competition between formal firms using informal practices. Specifically, two questions focus on focal formal firms competing against like formal firms that use the formal-informal continuum to reduce costs, taxes, and/or regulatory burdens. These questions are: "Does this establishment compete against registered firms selling goods/services without records or receipt?" (yes=1) and "Does this establishment compete against registered firms hiring workers without formal contracts?" (yes=1). Omitted from analysis are "don't know" responses (see Table 3 for percentages). The omission of records and receipts hides sales and taxes tied to sales both are classic examples of informal practices (Pisani, 2013). Utilizing unprotected and unreported labor is another prevalent form of informality (Portes \& Schauffler, 1993).

To save space, abbreviated results presenting the odds ratios are presented in Table $4 .{ }^{13}$ Below, the significant results for each country on both measures of formal firms competing informally are presented separately.

\footnotetext{
${ }^{13}$ Full results are available by request from the author.
} 


\subsubsection{Belize}

For Belizean formal firms reporting competition from peer firms operating, in part, informally, nine variables are significant (see Table 4). Increasing the odds of formal firm competition from formal firms not reporting or recording sales are (see Table 4, column 2 [Belize, Receipt]): industry classification, firm legal structure, the amount of time senior management spends dealing with government regulations, firm exports, and website presence. Specifically, private corporations and partnerships are 6.9 and 67.5 times more likely, respectively, than sole proprietorships/family businesses to face competition from formal firms selling goods off the books. As senior management undertakes more time focused on government regulations, so too do formal firms face increased odds of competition from peer firms at the rate of $18.3 \%$ per $1 \%$ increase in senior management time spent dealing with government regulations. Additionally, firms that export and firms with websites are $99.7 \%$ and $183.1 \%$, respectively, more likely to face competitive pressures from peer firms selling goods without records or receipts. Reducing the likelihood of formal firms facing competition from peer firms selling off the books (without a receipt) includes industry segment, firm connection to a larger enterprise, female ownership participation, and the number of employees. Firms aggregated in the other services group are 65.9\% less likely than manufactures to experience competition from peer firms selling goods informally. Formal firms that are part of a larger firm as well as firms with female ownership participation are $77.4 \%$ and $50.2 \%$ less likely, respectively, to face competition from peer firms selling goods without records or receipts. Lastly, larger formal firms by number of employees are $2.5 \%$ less likely per employee to face competition from peer formal selling off the books.

Increasing the odds of formal Belizean firms that compete against peer firms using informal labor are firm maturity, industry classification, firm legal structure, and exports (see Table 4, column 3 [Belize, Labor]). For each additional year of operation, Belizean formal firms are 3.1\% more likely to face competition from peer firms employing, in part, informal labor. Private corporations and partnerships are 14.3 and 104.7 times more likely, respectively, than formal sole proprietorships/family businesses to engage peer competitors utilizing informal labor. Lastly, formal exporters are 5.5 times more likely to compete against peer firms employing informal labor. Formal firms providing other services vis-à-vis manufacturers reduce their odds of competition by $75.2 \%$ against peer firms using informal labor. Female participation in the ownership structure of a formal Belizean firm reduces the likelihood by $89.7 \%$ of competition with a peer formal firm hiring informal labor. When senior management spends time dealing with government regulations, it reduces the odds of competition (by $9.2 \%$ per $1 \%$ increase in time spent) with peer firms employing informal labor. Finally, larger firms are less likely to undertake competition from peer firms, at the rate of $2.5 \%$ per additional employee. 
Table 4 Logistic Regression Results (odds ratios only) for Focal Formal Firms Competing Against Formal Firms Operating in Part Informally (Yes=1)

\begin{tabular}{|c|c|c|c|c|c|c|}
\hline & \multicolumn{2}{|c|}{ Honduras } & \multicolumn{2}{|c|}{ Nicaragua } & \multicolumn{2}{|c|}{ Panama } \\
\hline & Receipt & Labor & Receipt & Labor & Receipt & Labor \\
\hline Variables+ & $\operatorname{Exp}(\beta)$ & $\operatorname{Exp}(\beta)$ & $\operatorname{Exp}(\beta)$ & $\operatorname{Exp}(\beta)$ & $\operatorname{Exp}(\beta)$ & $\operatorname{Exp}(\beta)$ \\
\hline Constant & $.192 \neq$ & $.153 \neq$ & $12.340 \neq$ & 1.473 & $.010 \neq$ & $.018 \neq$ \\
\hline Firm Age (years) & $1.020 \neq$ & $1.020 \neq$ & 1.005 & 1.005 & $1.059 \neq$ & $1.042 \neq$ \\
\hline Location (Capital =1) & $.874^{*}$ & .907 & $2.061 \neq$ & 1.152 & $.301 \neq$ & $.484 \neq$ \\
\hline Industry Classification & $-*$ & + & + & - & $-\neq$ & + \\
\hline Retail & $3.226 \neq$ & $1.724 \neq$ & .903 & 1.192 & $.636 \neq$ & $.193 \neq$ \\
\hline Other Services & .964 & $.609 \neq$ & $1.406+$ & .993 & .870 & $.495 \neq$ \\
\hline Legal Status of the Firm & $-\neq$ & $\neq$ & $-\neq$ & -+ & + & $-\neq$ \\
\hline Public Corporation & $.663 \neq$ & $.710 \neq$ & .996 & $.573 \neq$ & $6.369 \neq$ & $.621 \neq$ \\
\hline Private Corporation & $.563 \neq$ & $.628 \neq$ & $4.030 \neq$ & $2.159 \neq$ & $1.632 \neq$ & $2.514 \neq$ \\
\hline Partnership & $.346 \neq$ & $.160 \neq$ & $.631+$ & $2.909 \neq$ & $.202 \neq$ & $6.096+E 8$ \\
\hline Other/NGO/Don't Know & $.137 \neq$ & $.113 \neq$ & - & - & - & - \\
\hline Focal Firm Part of a Larger Business? (yes $=1$ ) & $.455 \neq$ & $.420 \neq$ & $.263 \neq$ & $.580 \neq$ & $.495 \neq$ & .996 \\
\hline Female Ownership Participation (yes=1) & $3.137 \neq$ & $3.330 \neq$ & .945 & 1.026 & $.274 \neq$ & $.416 \neq$ \\
\hline $\begin{array}{l}\text { \%. Amount of Time Senior ManagementSpends } \\
\text { Dealing with Government Regulations }\end{array}$ & $1.005 \neq$ & $1.004 \neq$ & $1.005 \neq$ & 1.000 & $1.026 \neq$ & $1.007 \neq$ \\
\hline $\begin{array}{l}\text { Internationally Recognized Quality Certificate } \\
\text { (yes=1) }\end{array}$ & $3.525 \neq$ & $2.442 \neq$ & $.219 \neq$ & $.443 \neq$ & 22.653\# & $4.088 \neq$ \\
\hline Website (yes=1) & $.468 \neq$ & $.625 \neq$ & 1.172 & 1.175 & $7.571 \neq$ & $8.864 \neq$ \\
\hline Does Firm Export? (yes=1) & $4.009 \neq$ & $8.319 \neq$ & $.524 \neq$ & $1.847 \neq$ & $1.707 \neq$ & $5.101 \neq$ \\
\hline Number of Full-time Employees & $.999 \neq$ & $.999 \neq$ & $.997 \neq$ & 1.000 & $1.008 \neq$ & $1.001^{*}$ \\
\hline \multicolumn{7}{|l|}{ Model Diagnostics } \\
\hline $\begin{array}{l}\text {-2 Log Likelihood- } \\
\text { significance level - }\end{array}$ & $\begin{array}{c}5275.773 \\
.000 \neq\end{array}$ & $\begin{array}{c}5144.765 \\
.000 \neq\end{array}$ & $\begin{array}{c}2232.456 \\
.000 \neq\end{array}$ & $\begin{array}{c}2361.814 \\
.000 \neq\end{array}$ & $\begin{array}{c}4334.736 \\
.000 \neq\end{array}$ & $\begin{array}{c}4817.307 \\
.000 \neq\end{array}$ \\
\hline Cox \& Snell R2- & .139 & .142 & .141 & .080 & .402 & .261 \\
\hline Nagelkerke $R^{2}$ - & .191 & .195 & .188 & .107 & .536 & .356 \\
\hline \multicolumn{7}{|l|}{ Hit Ratio (96): } \\
\hline Yes - & 46.9 & 35.0 & 59.9 & 44.2 & 78.6 & 83.9 \\
\hline No- & 86.2 & 87.4 & 71.3 & 76.7 & 85.8 & 64.0 \\
\hline Overall- & 72.4 & 68.6 & 66.2 & 61.9 & 82.5 & 76.4 \\
\hline${ }^{*} \mathrm{C}_{\text {rio }} \cdot 1.25$ & 66.4 & 65.8 & 63.2 & 64.2 & 62.5 & 66.1 \\
\hline
\end{tabular}

Notes: +Reference categories= Location, Capital; Industry, manufacturing; Legal status of the firm, sole proprietorship/family business; Female Ownership, yes;

Internationally-recognized quality certificate, yes; Website, yes; Export, yes.

$\wedge$ Bold Represents significance at the ${ }^{*} \mathrm{P}<0.10 ; \nmid \mathrm{P}<0.05$; and $\neq \mathrm{P}<0.01$ levels. ${ }^{*} \mathrm{CPRO}=$ the proportional chance criterion $* 1.25$.

Source: Authors' calculations from the 2010 Enterprise Surveys. 
Table 4 (Continued): Logistic Regression Results (odds ratios only) for Focal Formal Firms Competing Against Formal Firms Operating in Part Informally (Yes=1)

\begin{tabular}{|c|c|c|c|c|c|c|}
\hline & \multicolumn{2}{|c|}{ Honduras } & \multicolumn{2}{|c|}{ Nicaragua } & \multicolumn{2}{|c|}{ Panama } \\
\hline & Receipt & Labor & Receipt & Labor & Receipt & Labor \\
\hline Variablest & $\operatorname{Exp}(\beta)$ & $\operatorname{Exp}(\beta)$ & $\operatorname{Exp}(\beta)$ & $\operatorname{Exp}(\beta)$ & $\operatorname{Exp}(\beta)$ & $\operatorname{Exp}(\beta)$ \\
\hline Constant & $.192 \neq$ & $.153 \neq$ & $12.340 \neq$ & 1.473 & $.010 \neq$ & $.018 \neq$ \\
\hline Firm Age (years) & $1.020 \neq$ & $1.020 \neq$ & 1.005 & 1.005 & $1.059 \neq$ & $1.042 \neq$ \\
\hline Location (Capital =1) & $.874^{*}$ & .907 & $2.061 \neq$ & 1.152 & $.301 \neq$ & $.484 \neq$ \\
\hline Industry Clas sification & + & $-\neq$ & + & - & + & $-\neq$ \\
\hline Retail & $3.226 \neq$ & $1.724 \neq$ & .903 & 1.192 & $.636 \neq$ & $.193 \neq$ \\
\hline Other Services & .964 & $.609 \neq$ & $1.406+$ & .993 & .870 & $.495 \neq$ \\
\hline Legal Status of the Firm & $\neq$ & + & 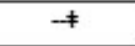 & + & + & + \\
\hline Public Corporation & $.663 \neq$ & $.710 \neq$ & .996 & $.573 \neq$ & $6.369 \neq$ & $.621 \neq$ \\
\hline Private Corporation & $.563 \neq$ & $.628 \neq$ & $4.030 \neq$ & $2.159 \neq$ & $1.632 \neq$ & 2.514\# \\
\hline Partnership & $.346 \neq$ & $.160 \neq$ & $.631+$ & $2.909 \neq$ & $.202 \neq$ & $6.096+E 8$ \\
\hline Other/NGO/Don't Know & $.137 \neq$ & $.113 \neq$ & - & - & - & - \\
\hline Focal Firm Part of a Larger Business? (yes=1) & $.455 \neq$ & $.420 \neq$ & $.263 \neq$ & $.580 \neq$ & $.495 \neq$ & .996 \\
\hline Female Ownership Participation (yes $=1$ ) & $3.137 \neq$ & $3.330 \neq$ & .945 & 1.026 & $.274 \neq$ & $.416 \neq$ \\
\hline $\begin{array}{l}\text { \% Amount of Time Senior ManagementSpends } \\
\text { Dealing with Government Regulations }\end{array}$ & $1.005 \neq$ & $1.004 \neq$ & $1.005 \neq$ & 1.000 & $1.026 \neq$ & $1.007 \neq$ \\
\hline $\begin{array}{l}\text { Internationally Recognized Quality Certificate } \\
\text { (yes=1) }\end{array}$ & $3.525 \neq$ & $2.442 \neq$ & $.219 \neq$ & $.443 \neq$ & $22.653 \neq$ & 4.088\# \\
\hline Website (yes $=1$ ) & $.468 \neq$ & $.625 \neq$ & 1.172 & 1.175 & 7.571\# & 8.864‡ \\
\hline Does Firm Export? (yes=1) & $4.009 \neq$ & $8.319 \neq$ & $.524 \neq$ & $1.847 \neq$ & $1.707 \neq$ & $5.101 \neq$ \\
\hline Number of Full-time Employees & $.999 \neq$ & $.999 \neq$ & $.997 \neq$ & 1.000 & $1.008 \neq$ & $1.001^{*}$ \\
\hline \multicolumn{7}{|l|}{ Model Diagnostics } \\
\hline -2 Log Likelihood- & 5275.773 & 5144.765 & 2232.456 & 2361.814 & 4334.736 & 4817.307 \\
\hline significance level - & $.000 \neq$ & $.000 \neq$ & $.000 \neq$ & $.000 \neq$ & $.000 \neq$ & $.000 \neq$ \\
\hline Cox \& Snell R²- & .139 & .142 & .141 & .080 & .402 & .261 \\
\hline Nagelkerke $R^{2}$ - & .191 & .195 & .188 & .107 & .536 & .356 \\
\hline \multicolumn{7}{|l|}{ Hit Ratio (96): } \\
\hline Yes - & 46.9 & 35.0 & 59.9 & 44.2 & 78.6 & 83.9 \\
\hline No- & 86.2 & 87.4 & 71.3 & 76.7 & 85.8 & 64.0 \\
\hline Overall- & 72.4 & 68.6 & 66.2 & 61.9 & 82.5 & 76.4 \\
\hline${ }^{*} \mathrm{C}_{r \times 0} \cdot 1.25$ & 66.4 & 65.8 & 63.2 & 64.2 & 62.5 & 66.1 \\
\hline
\end{tabular}

Notes: +Reference categories= Location, Capital; Industry, manufacturing; Legal status of the firm, sole proprietorship/family business; Female Ownership, yes;

Internationally-recognized quality certificate, yes; Website, yes; Export, yes.

$\wedge$ Bold Represents significance at the ${ }^{*} \mathrm{P}<0.10 ; \dagger \mathrm{P}<0.05$; and $\neq \mathrm{P}<0.01$ levels. ${ }^{*} \mathrm{CPRO}=$ the proportional chance criterion $* 1.25$.

Source: Authors' calculations from the 2010 Enterprise Surveys. 


\subsubsection{Costa Rica}

For Costa Rican formal firms competing against peer firms selling goods off the books without a receipt, two variables increase the odds of greater competition: firm age and firms with exports. As firms mature, each additional year in operation increases the likelihood of competition by $0.7 \%$ and firms that export are $71.6 \%$ more likely to face formal non-exporting peers selling informally. Five variables significantly reduce the odds of formal firm competition with peer firms selling goods informally; these are location, industry classification, firm legal structure, quality certification, and firm size. Formal firms located in the capital are $60.9 \%$ less likely to face competition from peer firms selling informally. Formal retailers and other services are $60.5 \%$ and $73.1 \%$, respectively, less likely than manufacturers to encounter competitive pressures from peer firms selling informally. As compared to sole proprietorships/family businesses, public corporations, partnerships, and others are $60.3 \%, 91.7 \%$, and $74.0 \%$, respectively, less likely to face peer firms selling informally. Costa Rican firms engaged in internationally recognized quality initiatives reduce their odds of formal peer competitors selling informally by $19.1 \%$. Lastly, firms with larger numbers of employees are less likely to face peer competition selling off the books at the rate of $0.1 \%$ per additional employee.

Under the formal competitive tactic of utilizing informal labor, nine variables significantly alter the odds of the competitive environment in Costa Rica. Increasing the odds of competitive pressures is firm location, firm legal status, firm connection to a larger enterprise, exports, and firm size. Location within the capital city increases the likelihood of peer firms employing informal labor by $71.4 \%$. In reference to sole proprietorships/ family businesses, private corporations, partnerships, and other legal forms are 5.5, 2.7, and 1.9 times more likely, respectively, to face competition from peer formal firms using informal labor practices. Formal firms that are part of a larger business enterprise as well as firms that export are $328.3 \%$ and 61.5\%, respectively, more likely to encounter peer firms hiring informal labor. Firm size, as measured by number of employees, also increases the odds of peer competition using informal labor practices at the rate of $0.1 \%$ per additional employee. Four variables significantly reduce the likelihood of peer firms employing informal labor; these are firm age, industry classification, ownership structure, and quality certification. As formal firms mature, they reduce the odds of facing peer initiative informal labor practices from their peers at the rate of $2.5 \%$ per year in business. Retailers and other service firms are $37.2 \%$ and $70.1 \%$, respectively, less likely to face peer firms utilizing informal labor practices as compared to manufacturers in Costa Rica. Lastly, female participation in the ownership structure and participation in internationally recognized quality initiatives reduce the odds each by $66.5 \%$ and $52.6 \%$, respectively, of peer firms employing informal labor practices.

\subsubsection{E1 Salvador}

Nine variables significantly differentiate formal Salvadoran firms that face competition from peer firms selling goods without a receipt, in part, informally. Increasing the likelihood of peer competition is quality certification, presence on the World Wide Web, and exports. Salvadoran firms with an internationally recognized quality certification are 1.1 times more likely to face formal peers without such quality certification selling goods informally (i.e., without records or a receipt). Those firms with a website as well as those firms that export are $75.5 \%$ and $92.9 \%$, respectively, more likely to compete against peer firms selling informally. On the other hand, six variables reduce the likelihood of formal firms competing against peer firms selling goods, in part, informally. These are: firm age, firm location, firm industry classification, legal status of the firm, the amount of time senior management spends on dealing with government regulations, and the number of employees. Firm maturity reduces the odds of competition from peer firms selling informally by $0.5 \%$ per additional year in business. Location in the capital city of San Salvador decreases the likelihood of competition by $56.4 \%$ against 
like firms selling informally. As compared to manufacturers, retailers and other services are $82.7 \%$ and $76.6 \%$, respectively, less likely to face peer competitors selling informally. In relation to sole proprietorships/family businesses, partnerships and other legal forms of business organization are $98.9 \%$ and $74.0 \%$, respectively, to engage in competition with peer firms selling goods informally. As senior management spends more time dealing with government regulations, these formal Salvadoran firms are less likely to face peer competitors selling informally at the rate of $1.0 \%$ per an equal amount of time spent on government regulations. Lastly, firm size reduces the likelihood of peer competition selling off the books at the rate of $0.1 \%$ per additional employee.

Nearly all the variables estimated for formal firm competition vis-à-vis peers employing informal labor are significant for urban Salvadoran enterprises. Firm maturity reduces the odds of peers using informal labor by $2.2 \%$ per year in business. Location in the capital, likewise, reduces the odds of peer competitors employing informal labor by $40.7 \%$. Formal sector retailers and other service providers are $61.7 \%$ and $62.9 \%$, respectively, less likely than manufacturers to utilize informal laborers. With reference to sole proprietorships/family businesses, partnership, public corporations and private corporations, are $96.9 \%$ less, 58.5\% less, and 52.3\% more likely, respectively, to compete against peer firms employing informal labor. The more senior management deals with government regulations the less likely a firm is to compete against peers using informal labor (at the rate of $0.9 \%$ per $1 \%$ increase in senior management time spent on regulations). And the presence of a firm website reduces the odds by $36.6 \%$ of a competitor employing informal labor. If a firm is a component of a larger firm, then odds of peer competitors using informal labor increases by $30.4 \%$. Exporters and firms with an internationally recognized quality certificate are 1.1 and 2.4 times, respectively, more likely to face peer competitors who hire informal labor.

\subsubsection{Guatemala}

With regard to selling goods informally without a receipt, eight variables are significant in Guatemala. In Guatemala as formal enterprises age, they are more likely to face peer competitors selling goods without proper records or receipts at the rate of $0.8 \%$ per additional year in business. Additionally, formal firms with an internationally recognized quality certification as well as presence on the Internet are 17.9 and 1.0 times more likely, respectively, to engage peer competitors selling goods informally. Retailers and other service providers, on the other hand, are $138.4 \%$ and $59.7 \%$, respectively, less likely than manufacturers to face peer competitors selling off the books. In relation to sole proprietorships/family businesses, public corporations, private corporations, and partnerships are $75.1 \%$ less likely, $12.5 \%$ more likely, and 8.4 times more likely, respectively, to compete against peer firms selling informally. Additionally, being part of a larger enterprise and firms with female ownership participation reduce the odds, by $63.2 \%$ and $28.3 \%$, respectively, of peer competitors selling, in part, informally. While significant, company size does not have a meaningful impact regarding peer firms selling informally.

Similar to selling informally, as Guatemalan firms age, formal firms are more likely to face peer competitors utilizing informal labor (at the rate of $1.3 \%$ per additional year in business). Six other variables are significant regarding hiring informal labor. Formal enterprises located in the capital city of Guatemala City are $83.4 \%$ more likely to compete against peer firms employing, in part, informal labor. In relation to manufacturers, retailers and other service providers are $21.7 \%$ and $72.6 \%$ less likely, respectively, to face peer firms using informal labor. As compared to sole proprietorships/family businesses, public corporations, private corporations, and partnerships are $94.1 \%$ less likely, 50.7\% more likely, and 39.4\% less likely, respectively, to compete against peer firms hiring informal labor. Firms that are part of larger firms reduce their odds of competing against 
peer firms employing labor informally by $80.5 \%$. When women are part of the ownership structure of the firm, these firms reduce their odds by $30.1 \%$ of peer firms competing informally using informal labor. Lastly, as firms grow in size, they reduce their odds of competing against peer firms hiring informal labor at the rate of $0.1 \%$ per additional employee.

\subsubsection{Honduras}

Across both informal tactics, twenty of twenty-one variables are significant in Honduras. In Honduras, firm maturity is associated with an increased likelihood of formal enterprises competing against peer formal counterparts selling goods without a receipt informally at the rate of $2.0 \%$ per additional year in business. Retailers are 1.2 times more likely to face peer competitors selling goods off the books than manufacturers. If the ownership structure of a firm includes female participation, then these firms are 2.1 times more likely to engage peer competitors selling goods off the books. When senior management is more involved in dealing with government regulations, so too is the firm more likely to face peer competitors selling informally (at the rate of $0.5 \%$ per $1 \%$ increase in senior management time spent on government regulations). Internationally recognized quality certification and firms that export increase the odds of peer competitors selling goods without appropriate record keeping or receipts by 2.5 and 3.0 times, respectively. Formal firms located in Tegucigalpa, the capital of Honduras, reduce their chances of facing peer firms selling informally by $12.6 \%$. In reference to sole proprietorships/family businesses, public corporations, private corporations, partnerships, and other legally structured organization are $33.7 \%, 43.7 \%, 65.4 \%$, and $86.3 \%$, respectively, less likely to engage peer competitors selling goods informally. Enterprises that are part of a larger firm and firms with a website are $54.5 \%$ and $53.2 \%$ less likely, respectively, to compete against peer firms selling informally. Lastly, firm size decreases the odds of facing peer firms selling, in part, informally (at the rate of $0.1 \%$ per additional employee).

Honduran formal firms as they age are more likely to encounter peer firms hiring labor, in part, informally (at the rate of $2.0 \%$ per additional year in business). In reference to manufacturing enterprises, retailers and other service providers are $72.4 \%$ more likely and $39.1 \%$ less likely, respectively, to face peer competitors employing informal labor. If female participation in the ownership structure of the firm is present, then these firms are 2.3 times more likely to face peer competitors utilizing informal labor. Also increasing the odds of peer firms using informal labor is the amount of time spent by senior management focused on government regulations (at the rate of $0.4 \%$ per additional $1 \%$ of time spent concerned with government regulations). Honduran enterprises possessing an internationally recognized quality certificate and exporters are 1.4 and 7.3 more times, respectively, to face peer competitors hiring labor informally. In relation to sole proprietorships/family businesses, public corporations, private corporations, partnerships, and other legal forms of organization are $29.0 \%, 37.2 \%, 84.0 \%$, and $88.7 \%$ less likely, respectively, to take on competitors hiring informal labor. Enterprises that are part of a larger firm and firms with websites are $68.0 \%$ and $37.5 \%$ less likely, respectively, to encounter peer competitors hiring labor off the books. Lastly, as firms grow, they reduce the odds of peer competitors using informal labor (at the rate of $0.1 \%$ per additional employee).

\subsubsection{Nicaragua}

Nicaraguan formal enterprises located in the capital of Managua increase their odds of facing peer competitors selling goods without appropriate record keeping or receipts, in part, informally by $106.1 \%$. Seven other variables significantly impact firms competing against peers selling off the books. Other service providers are $40.6 \%$ more likely to compete against peer enterprises in reference to manufacturers. In relation to sole proprietorships/family businesses, private corporations are 3.0 times more likely, and partnerships are 36.9\% 
less likely, respectively, to encounter peer firms selling goods off the books. In Nicaraguan enterprises where the senior management spends more time dealing with government regulations, these firms face increased odds of peer firms selling goods informally (at the rate of $0.5 \%$ per additional $1 \%$ of senior management time spent focused on government regulations). Enterprises that are part of a larger firm are $73.7 \%$ less likely to compete against peer firms selling goods informally. Firms that possess an internationally recognized quality certificate as well as firms that export are $78.1 \%$ and $47.6 \%$, respectively, less likely to encounter peer firms selling goods informally. Lastly, larger firms by the number of employees are $0.3 \%$ less likely per additional employee to compete informally against peer firms.

For Nicaraguan formal firms facing formal competitors who hire labor, in part, informally, four variables significantly impact the competitive environment: firm legal status, firm composition, quality certification, and exports. In reference to sole proprietorships/family businesses, public corporations, private corporations, and partnerships are $42.7 \%$ less likely, $115.9 \%$ more likely, and 190.9\% more likely, respectively, to compete against peer firms employing informal labor. Nicaraguan firms that are part of a larger firm are 42.0\% less likely to compete against peer firms hiring informal labor. Enterprises with an internationally recognized quality certification reduce their odds of competing against peer firm hiring informal labor by 55.7\%. Lastly, exporters are $84.7 \%$ less likely to encounter peer firms utilizing informal labor.

\subsubsection{Panama}

Panamanian formal firms face significant competitive pressures from peer firms across most every variable examined. As formal enterprises in Panama mature, they are more likely to encounter competitive pressures from peer firms selling goods informally without a receipt (at the rate of 5.9\% per additional year in operation). In reference to sole proprietorships/family businesses, public corporations, private corporations, and partnerships are 536.9\% more likely, 63.2\% more likely, and 79.8\% less likely, respectively, to compete against peer businesses selling goods off the books. Enterprises where senior management spends more time dealing with government regulation are more likely to face peer firms selling goods informally (at the rate of $2.6 \%$ per additional $1 \%$ of time spent on government regulations). Panamanian firms with an internationally recognized quality certification increase their odds by 21.6 times that they will encounter peer firms selling goods off the books. Formal businesses that possess a website and those that export are $657.1 \%$ and $70.7 \%$ more likely, respectively, to compete against formal peers selling goods informally. Lastly, as formal firms grow in their number of employees, so too do the odds of competing against peer firms selling goods without appropriate record keeping or receipts (at the rate of $0.8 \%$ per additional employee).

Reducing the odds of competing against peer firms includes firm location, industry classification, firm composition, and ownership structure. Firms located in the capital city of Panama are 69.9\% less likely to compete against peers selling informally. In relation to manufacturers, retailers are $36.4 \%$ less likely to compete against firms selling goods informally. If a formal firm is part of a larger firm, then that firm reduces its odds by $50.5 \%$ of competing against peer firms selling goods informally. Lastly, firms with female ownership are 72.6\% less likely to undertake competition from peer firms selling informally.

In Panama as formal firms' age, they are more likely to face peer competitors employing informal labor tactics (at the rate of $4.2 \%$ per additional year in business). Senior managers in formal firms who spend more time dealing with government regulations increase the likelihood of peer competitors using informal labor (at the rate of $0.7 \%$ per additional $1 \%$ of time spent focused on government regulations). Enterprises with an internationally recognized quality certification, a web presence, and exports, are 3.1, 7.9, and 4.1 times more 
likely, respectively, to compete against peer firms that hire informal labor. Additionally, larger firms by number of employees increase their odds of competing against peer firms hiring informal labor (at the rate of $0.1 \%$ per additional employee).

Firm location in the capital reduces the odds by $51.6 \%$ that these firms will compete against peer firms using informal labor. In reference to manufacturers, retailers and other service providers are $80.7 \%$ and $50.5 \%$ less likely, respectively, to compete against peer firms utilizing informal labor. As compared against sole proprietorships/family businesses, public corporations and private corporations are $37.9 \%$ less likely and $151.4 \%$ more likely, respectively, to face competition from peer firms hiring informal labor. Lastly, enterprises with female participation in the ownership structure are 58.4\% less likely to compete against peer firms who hire informal labor.

\section{SuMmary \& DISCUSSION}

To make more sense of the above recitation of data, observed general patterns across Central America by type of informal tactic - selling goods informally without a receipt and hiring informal labor-are summarized. In determining a general pattern, a minimum benchmark of at least two-thirds of the significant independent variable observations possess the same directional likelihood (e.g., more likely, or less likely) is needed, otherwise the pattern is indeterminate. Together, anticipated, and actual results are presented in Table 5.

For the first informal tactic studied, six variables generally increase the odds of formal Central American enterprises competing against formal peer firms, in part, selling goods informally without a receipt. These variables are: firm age, firm legal status as a private corporation, amount of senior management time spent dealing with government regulations, possession of an internationally recognized quality certificate, website presence, and exports. In brief, older firms are more likely to face peer competitors selling goods off the books. Private corporations, in relation to sole proprietorships/family businesses, encounter greater odds of peer competitors selling goods informally. Firms that spend increasing amounts of senior management time focused on government regulations are more likely to compete against peers selling goods without appropriate record keeping or sales receipts. Acquisition of an internationally recognized quality certification increases the odds of competing against peer firms selling goods informally. A firm website enhances the likelihood of peer competition where that competition sells goods, in part, informally. Lastly, firms that export increase their odds of facing peer competitors selling informal goods.

Six variables generally reduce the likelihood of formal Central American firms competing against peers selling, in part, goods off the books without a receipt. These six variables are: firm location, industry classification, legal status of the firm (i.e., public corporations and partnerships), firm composition (e.g., part of a larger firm), firm ownership structure that includes female ownership participation, and firm size (i.e., number of employees). Formal firms located in their country's respective capital reduce their odds of facing peer competitors selling goods informally. In reference to manufacturers, retailers and other service providers are less likely to encounter peer competition selling goods off the books. Public corporations and partnerships are less likely than sole proprietorships/family businesses to face peer competitors selling goods without appropriate record keeping or sales receipts. Formal Central American firms that are part of larger firms are less likely to compete against peers from stand-alone businesses selling goods informally. Firms with female participation in the ownership structure are less likely to compete against firms selling goods off the books than their male-only owned counterparts. Lastly, larger firms as measured by the number of employees reduce their odds of peer competitors utilizing the informal tactic of selling goods informally. 
Table 5 Summary of Anticipated and Actual Results for Formal Firms Competing Against Peer Formal Firms Using Informal Tactics

\begin{tabular}{|c|c|c|c|}
\hline & & \multicolumn{2}{|c|}{ Actual Results } \\
\hline Variable & Anticipated Results & No Receipt & Informal Labor \\
\hline Firm Age & Indeterminate & Increase Informal Practice & Increase Informal Practice \\
\hline Capital Location & Reduce Informal Practice & Reduce Informal Practice & $\cdots$ \\
\hline Industry Classification & $\begin{array}{l}\text { Increase Informal Practice of Retailers and Other } \\
\text { Services vis-à-vis Manufacturers }\end{array}$ & $\begin{array}{l}\text { Reduce Informal Practice for both Retailers } \\
\text { and Other Services vis-à-vis Manufacturers }\end{array}$ & $\begin{array}{l}\text { Reduce Informal Practice for both Retailers } \\
\text { and Other Services vis-à-vis Manufacturers }\end{array}$ \\
\hline Legal Status of the Firm & $\begin{array}{c}\text { Reduce Informal Practice of Public Corporations, } \\
\text { Private Corporations and Partnerships vis-à-vis Sole } \\
\text { Proprietorships/Family Businesses }\end{array}$ & $\begin{array}{l}\text { Increase Informal Practices of Private } \\
\text { Corporations vis-à-vis Sole } \\
\text { Proprietorships/Family Businesses } \\
\text { Decrease Informal Practices of Public } \\
\text { Corporations and Partnerships vis-à-vis Sole } \\
\text { Proprietorships/Family Businesses }\end{array}$ & $\begin{array}{l}\text { Increase Informal Practices of Private } \\
\text { Corporations vis-à-vis Sole } \\
\text { Proprietorships/Family Businesses } \\
\text { Decrease Informal Practices of Public } \\
\text { Corporations vis-à-vis Sole } \\
\text { Proprietorships/Family Businesses }\end{array}$ \\
\hline Focal Firm is Part of a Larger Business & Reduce Informal Practice & Reduce Informal Practice & $\cdots$ \\
\hline Female Ownership Participation & Reduce Informal Practice & Reduce Informal Practice & Reduce Informal Practice \\
\hline $\begin{array}{l}\text { Amount of Time Senior Management } \\
\text { Spends Dealing with Government } \\
\text { Regulations }\end{array}$ & Indeterminate & Increase Informal Practice & $\cdots$ \\
\hline $\begin{array}{l}\text { Possess Internationally Recognized } \\
\text { Quality Certificate }\end{array}$ & Reduce Informal Practice & Increase Informal Practice & $-\cdots$ \\
\hline Possess a Website & Indeterminate & Increase Informal Practice & $\cdots$ \\
\hline Exporter & Reduce Informal Practice & Increase Informal Practice & Increase Informal Practice \\
\hline Number of Full-time Employees & Indeterminate & Reduce Informal Practice & $\ldots$ \\
\hline
\end{tabular}

Source: Author's calculations from the 2010 Enterprise Surveys.

The generalized patterns for the second tactic studied, the hiring of informal labor, are less definitive across all the variables. Nevertheless, three variables - firm age, legal status of the firm as a private corporation, and exports - are generally associated with an increase in the odds of formal firms competing against peers employing informal labor. In short, more mature firms increase their odds of facing younger peer firms who hire, in part, informal labor. Private corporations as compared to sole proprietorships/family businesses are more likely to encounter peer competitors who engage in informal labor practices. Firms that export are more likely to compete against peers (e.g., non-exporters) who utilize informal labor.

Three variables are also generally associated with a reduction in competitive pressures of peer firms hiring informal labor; these are: industry classification, legal status of the firm as a public corporation, and female participation in the firm ownership structure. In reference to manufacturers, retailers and other service providers are less likely to encounter competitors who hire labor informally. As compared to sole proprietorships/family businesses, public corporations are likely less to face peer competitors using informal labor. Lastly, firms with female participation in their ownership structure reduce their odds of competing against peer firms employing labor informally.

There also exist some generalized patterns across the two informal tactics, perhaps reinforcing the robustness of these variables in relation to formal Central American firms facing peer firms operating, in part, informally. Older firms, private corporations (in reference to sole proprietorships/family businesses), and exporters all increase their odds of competing against peer firms selling goods off the books without a receipt and hiring informal labor. Retailers and other service providers (in relation to manufacturers), public corporations (in reference to sole proprietorships/family business), and participation of women in the ownership structure of the firm all reduce the likelihood of competing against peer firms selling goods informally without a receipt and employing informal labor. 
The overall results for five variables earn some generalized comments. For all Central America, except Honduras, female participation in the ownership structure of formal enterprises diminishes the odds of competitive pressures from peer firms operating informally. While female owners are in the minority in all but one of the countries (Nicaragua), female ownership deters competitors from engaging in selling goods informally or employing informal labor, confirming the a priori expectations. As expected, public corporations across Central America (except in Panama) are better equipped and endowed to counter peers operating informally than sole proprietorships/family businesses. Hand in hand with this result is the ability of Central American firms that are part of larger firms (except in Costa Rica and El Salvador) to defend against peer firms operating informally. In contrast to a priori expectations, exporters face an increased likelihood of domestic competition for peer non-exporting firms. Perhaps the focus on the international marketplace provides space for peer firms to compete informally while exporters are more focused on the global economy. Also, in contrast to expectations, most retailers and other services providers are less likely to engage in competition from peers utilizing informal tactics vis-à-vis manufacturers. This finding may have more to do with manufacturers encountering peer competition employing informal tactics.

\section{Conclusion}

There are few studies of formal firms utilizing informal tactics in emerging markets where informality abounds. The research contribution of this article, as a first step forward, lies in the exploration of formal enterprises employing informal tactics against similar firms within the Central American region. The informal tactics previewed here include selling goods without proper record keeping or documentation (receipts) and the hiring of labor outside the legal framework of standard employment. These informal tactics are embedded within formal enterprises where it is difficult to discern which sales and which employees are formal and which are informal.

Simply put, informality is endemic in Central America and seeps into most aspects of economic life in the region (ILO, 2018). This includes the formal sector where formal firms deploy informal tactics for competitive balance and strategic advantage. At the national level in the region, the use of informal tactics by formal firms as reported by competitor formal firms is most prevalent in El Salvador (67.5\%) and least so in Belize (51.3\%). Clearly, more than half of formal enterprises across Central America report competing against like formal enterprises using informal means. At the firm level, formal enterprises that are older, engage in manufacturing, and export are more likely to face formal competitors utilizing informal tactics. Only female ownership, in part or in full, diminishes the likelihood of peer competition among formal enterprises.

The degree and challenge to which formal firms encounter peers using informal competitive tactics in the region is not inconsequential. Informality in various forms persists, in part, because of weak enforcement by the state and the competitive advantages of such tactics provide firms. In such an enforcement vacuum and permissive environment, informality flourishes even for those firms that are ostensibly part of the formal sector. The reward often outweighs the risk. This article has highlighted the determinants including those that encourage and those that dissuade informal behavior. Future research should further explore why these variables challenge formality and play a prominent role in the use and non-use of informal tactics within the formal sector. 
From a policy perspective, extending the regulatory environment to the informal economy in developing economies has proved mostly ineffective (Richter, 2019). Even within developed economies, robust pockets of informality survive (Pisani et al., 2017, Portes et al., 1989; Richardson \& Pisani, 2012). Those economies with the smallest informal sectors are also the most developed (Schneider \& Bajada, 2005); hence a prolonged period of real economic growth may be the most effective method of downsizing informality across sectors. In the short term, however, emerging and developing country governments may reduce the enforcement costs and policing problems associated with large informal sectors and actors through a redefinition of the sector based upon a minimum economic floor connected to sales and the number of employees (Pisani \& Ovando, 2019). In essence, this policy choice would make currently illegal practices for many, legal for smaller enterprises freeing up scarce government enforcement resources for more critical concerns as well as acknowledging existing and accepted practice.

\section{REFERENCES}

Bienefeld, Manfred (1975), “The Informal Sector and Peripheral Capitalism: The Case of Tanzania," Bulletin of the Institute of Development Studies, 6(Feb), 53-73.

Booth, John A., Christine J. Wade, and Thomas W. Walker (2015), Understanding Central America: Global Forces, Rebellion, and Change, 6th edition, Boulder, CO: Westview Press.

De Soto, Hernando (2000), The Mystery of Capital: Why Capitalism Triumphs in the West and Fails Everywhere Else, New York: Basic Books.

Funkhouser, Edward (1996), “The Urban Informal Sector in Central America: Household Survey Evidence," World Development, 24(11), 1737-1751.

House, William J. (1984), “Nairobi’s Informal Sector: Dynamic Entrepreneurs or Surplus Labor?” Economic Development and Cultural Change, 32(2), 277-302.

ILO (2018), Women and Men in the Informal Economy: A Statistical Picture, 3rd edition, Geneva, Switzerland: International Labour Office.

Neuwirth, Robert (2011), Stealth of Nations: The Global Rise of the Informal Economy, New York, NY: Pantheon Books.

Pampel, Fred C. (2000), Logistic Regression: A Primer, Thousand Oaks, CA: Sage Publications.

Pisani, Michael J. (2019a), The Informal Competitor Next Door: The Business Impact on Formal Enterprises in the Metropolitan Region of Paraguay, CADEP, Asunción, Paraguay.

Pisani, Michael J. (2019b), "From Informal to Formal: An Exploration of the Firm-Level Determinants of Sectoral Graduation in El Salvador," Academia Revista Latinoamericana de Administración, 32(1), 79-92.

Pisani, Michael J. (2018), “Contemporary Female Entrepreneurship in Nicaragua,” AD-minister, 33(2), 5-20.

Pisani, Michael J. (2017), "Entrepreneurship at the Base of the Pyramid: The Case of Nicaragua," in Colin C. Williams and Anjula

Gurtoo (Eds.), Handbook of Entrepreneurship in Developing Economies, New York, NY: Routledge, pp. 343-355.

Pisani, Michael J. (2016), “Disadvantaged? Informal Female Entrepreneurs Operating Tienditas in Nicaragua,” Ensayos Revista de Economía, 35(2), 195-223.

Pisani, Michael J. (2015), “Does Informality Impact Formal Sector Firms? A Case Study from Nicaragua,” Journal of Developing Areas, 49(2), 317-334.

Pisani, Michael J. (2013), Consumption, Informal Markets, and the Underground Economy: Hispanic Consumption in South Texas, New York, NY: Palgrave Macmillan.

Pisani, Michael J. (2003), “The Negative Impact of Structural Adjustment on Sectoral Earnings in Nicaragua," Review of Radical Political Economics, 35(2), 107-125. 
Pisani, Michael J., Joseph M. Guzman, Chad Richardson, Carlos Sepulveda, and Lyonel Laulié (2017), "Small Business Enterprises and Latino Entrepreneurship: An Enclave or Mainstream Activity in South Texas?” Journal of International Entrepreneurship, 15(3), 295-323.

Pisani, Michael J. and Fernando G. Ovando Rivarola (2019), Understanding the Determinants of Economic Informality in Paraguay: A Kaleidoscope of Measures, Cham, Switzerland: Palgrave Macmillan.

Pisani, Michael J. and José A. Pagán, (2004), “Sectoral Selection and Informality: A Nicaraguan Case Study,” Review of Development Economics, 8(4), 541-556.

Pisani, Michael J. and J. Michael Patrick (2002), "A Conceptual Model and Propositions for Bolstering Entrepreneurship in the Informal Sector: The Case of Central America," Journal of Developmental Entrepreneurship, 7(1), 95-111.

Pisani, Michael J. and Jana S. Pisani (2018), “'Off the Books' Consumption: Determinants and Practice in Belize, Central America," The Latin Americanist, 62(2), 213-241.

Pisani, Michael J. and Jana S. Pisani (2007), "The Contemporary Belizean View of the Economic Way Forward: Regional versus Global Perspectives," Journal of Belizean Studies, 29(1), 20-37.

Pisani, Michael J. and David W. Yoskowitz (2012), "A Study of Small Neighborhood Tienditas in Central America," Latin American Research Review, 47(4), 116-138.

Portes, Alejandro, Manuel Castells, and Lauren A. Benton (Eds.) (1989), The Informal Economy: Studies in Advanced and Less Developed Countries, Baltimore, MD: The Johns Hopkins University Press.

Portes, Alejandro, and Richard Schauffler, (1993), “Competing Perspectives on the Latin American Informal Sector," Population and Development Review, 19 (March): 33-60.

Richardson, Chad and Michael J. Pisani (2012), The Informal and Underground Economy of the South Texas Border, Austin, TX: University of Texas Press.

Richter, Jonas (2019), Formalisation Through Taxation: Paraguay's Approach and Its Implications, Cham, Switzerland: Palgrave Macmillan.

Schneider, Friedrich and Christopher Bajada (2005), Size, Causes and Consequences of the Underground Economy: An International Perspective, Aldershot, UK: Ashgate.

Vallanti, Giovanna and Giuseppina Gianfreda (2021), "Informality, Regulation and Productivity: Do Small Firms Escape EPL through Shadow Employment?” Small Business Economics, 57(3), 1383-1412.

Williams, Colin C. (2020), "Why do Informal Sector Competitors Hinder Formal Entrepreneurs More in Some Countries?” Revista de Empreendedorismo e Gestão de Pequena Empresas, 9(4), 718-743.

Williams, Colin C. and Youssef Youseff (2014), "Classifying Latin American Economies: A Degree off Informalisation Approach," International Journal of Business Administration, 5(3), 73-85.

West, Robert C. and John P. Augelli (1976), Middle America: Its Lands and Peoples, 2nd edition, Englewood Cliffs, NJ: Prentice-Hall, Inc.

World Bank (2013), “The Nicaragua 2010 Enterprise Survey Data Set," Accessed at: www.enterprisesurvey.org.

World Bank Group (2013), "Measuring Firm Performance in Latin America and the Caribbean," Latin America and the Caribbean Series No. 2, January. Accessed at: http://www.enterprisesurveys.org/ /media/FPDKM/ EnterpriseSurveys/Documents/Topic-Analysis/Measuring-Firm-Performance-LAC-Note-3.pdf.

World Bank (2009), "Enterprise Survey and Indicators Surveys: Sampling Methodology," Accessed at: http://microdata. worldbank.org/index.php/catalog/enterprise_surveys 


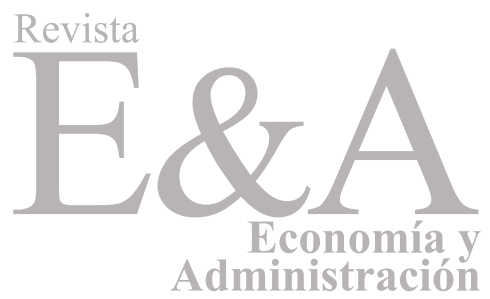

